\title{
The "Othering" of Men in Early Childhood Education: Applying Covey's Seven Habits
}

\author{
Kevin McGowan \\ Sam Houston State University
}

How do early childhood educators, parents, and administrators really feel about men working with young children? Should men work as teachers of young children from birth through 8 years of age? Is this women's work? Does explicitly and implicitly excluding men from the early childhood education workforce benefit the early childhood community's commitment to diversity? Young children should have a diverse range of experiences including learning from men in their early childhood education settings (Bullough, 2015). In order to effectively recruit and retain more men into the early childhood education profession, early childhood education staff, parents, and administrators have to address their overt and covert "othering" biases toward men working in early childhood education environments.

Edward Said (1978) coined the term "othering," or the societal marginalization of people based on some physical or mental characteristic. Said was specifically referring to Asian and Arab people and their "othering" experiences. In the years since 1978, social scientists and researchers have used the term "othering" to describe a plethora of marginalization experiences including gender. Most of the "othering" research on gender is concerned with the marginalization of women in a male dominated society; however, when it comes to early childhood education, men are often marginalized in a female dominated environment. Some of the "othering" can be overt such as accusing all men in early childhood education settings of being pedophiles, violent, or gay (Nelson, 2010; Pruit, 2014). In some instances, the "othering" experiences can be covert such as assuming that all men are good at putting together the housekeeping furniture for the dramatic play center, disciplining children who are not following the classroom rules, or participating in and organizing sporting events (Eisenhauer \& Pratt, 2010).

The following sections will discuss overt "othering" biases, covert "othering" biases, and the application of Stephen Covey's Seven Habits of Highly Effective People in addressing overt and covert "othering" biases. The seven habits are: (1) be proactive, (2) begin with the end in mind, (3) put first things first, (4) think win-win, (5) seek first to understand, then to be understood, (6) synergize, and (7) sharpen the saw (Covey, 2013).

\section{Overt "Othering" Biases}

Men Who Work with Young Children may be Perceived as Being Pedophiles

We must do everything that we can to protect children from men and women who want to harm them. Some of the ways that we ensure children's safety is to require that everyone in the child care center, regardless of gender, goes through the same rigorous background checks. All employees must receive up-todate professional development regarding the signs of sexual and physical abuse, and all early childhood education staff must be vigilant in their monitoring and observation of all adults who come into contact with children (Nelson, 2010).

\section{Men may be Perceived as Inherently Violent}

Some members of the early childhood education community think men are inherently violent and overly aggressive, thus negating any nurturing attributes they may have. To the contrary, men care for children as fathers, grandfathers, and uncles. Men can be very nurturing caregivers for infants, toddlers, and preschoolers. The nurturing skills that men possess in order to take care of their children can easily be transferred to the early childhood education environment (Eisenhauer \& Pratt, 2010; Johnson, Middleton, Nicholson, \& Sandrick, 2010). 


\section{Men Who Work with Young Children may be Per- ceived as Being Homosexual}

It is true that some male early childhood teachers are gay; however, it is also true that some male police officers, firefighters, and professional athletes are gay. A man's sexual orientation should not preclude him from a career in early childhood education (Nelson, 2010).

\section{Covert “Othering" Biases}

\section{Men may be Stereotyped as Being Naturally Better at Managing Children's Behavior}

Are men inherently better at managing children's behavior or is it a role assigned to them from the larger society? If society had assigned the role of primary disciplinarian to women, then they would be considered better at managing the behavior of children. Exposure to evidenced-based professional development on best-practice classroom management strategies will enhance classroom management for all early childhood teachers regardless of gender.

\section{Men are Often Thought to be Good Mechanical Technicians and Good Athletes}

All men should be good at repairing broken items, putting together furniture, and playing a variety of sports. Some men are very good repairmen and very athletic and some are not; some women are very good repairwomen and very athletic, and some are not. Think about sending out a general message requesting assistance with your broken furniture or repair requests. You may be surprised at who answers your call regarding repairing broken furniture or putting together bookshelves. Early childhood educators, parents, and administrators should not assume that the men in our early childhood centers and schools will take on all physical education activities. Early childhood education centers and schools will have to examine this from an individual perspective.

\section{Applying Stephen Covey's Seven Habits}

\section{Be Proactive}

Teachers and administrators in early childhood settings can talk to students and parents about early childhood teaching as an option for boys. Post pictures of men in early childhood settings who are engaged in the total classroom environment (e.g., cooking activities, changing diapers, feeding infants, reading stories, rocking children in rocking chairs), not just the activities that are traditionally assigned to men (e.g., disciplinarians, repairing broken furniture). Encourage boys to play in the dramatic play center. En- courage fathers to come in and volunteer. Encourage our allies and colleagues in the K-12 sectors to also promote the idea of men working as teachers in early childhood settings.

\section{Begin with the End in Mind}

It is December 31, 2026. What do you want your colleagues to say about your advocacy efforts related to men working in all aspects of early childhood education environments? Will they say you were an ally and advocate for men teaching in early childhood settings? The advocacy that we employ today will determine whether the early childhood community is having this same conversation about covert and overt "othering" biases in the near and distant future.

\section{Put First Things First}

The early childhood community will continue to work within its own ranks in terms of welcoming men to the early childhood profession. Make sure that the center policies are very explicit in terms of inclusion. During staff and parent meetings, remind everyone that discrimination will not be tolerated including discriminating against men because of their gender.

\section{Think Win-Win}

Let teachers and parents know that the center actively recruits the best teachers. Also inform them that some of the top candidates could be men and that some of these men will be working with the infants and toddlers including changing diapers. This is not men versus women. Everyone wins when the mostqualified candidates get the early childhood teaching jobs regardless of gender.

\section{Seek First to Understand, then to be Understood}

Be mindful of your thoughts and actions regarding men in early childhood education in general and to any men in your schools or centers in particular. Are your thoughts and actions "othering" men? Are we thinking about overt "othering" biases such as pedophilia, homosexuality, and violence? Are we thinking about covert "othering" biases such as repairmen, athletes, and disciplinarians? Seek first to understand the men as individuals via active listening and thoughtful responses.

\section{Synergize}

Lend your voice to others in the struggle for equality regarding men working in early childhood education via joining groups that advocate for men teaching and caring for young children (e.g., National Association for the Education of Young Children, Men- 
Teach).

\section{Sharpen the Saw}

Covey (2013) stated that a dull saw will not be very effective in cutting wood. Just as a dull saw will not cut wood, a fatigued mind and tired body will not function at its optimal level. In order for us to actively monitor and screen our own covert and overt "othering" biases and the biases of others, we have to take time to energize our minds and bodies. With relaxed minds and energized bodies, the early childhood education community can do the heavy lifting related to addressing the covert and overt "othering" biases regarding men in early childhood education.

\section{Conclusion}

Young children, from birth through age 8, need to be exposed to a wide range of experiences. One of these experiences is interacting with highly-qualified and caring male teachers in early childhood environments (Bullough, 2015). In order to ensure that more male teachers are hired for early childhood education classrooms, early childhood staff and parents have to be aware of gender-based biases. In addition, since administrators play a pivotal role in who gets hired, it is important for them to be aware of biases toward male early childhood teachers. As teachers, parents, and administrators become aware of their biases, they can address them via applying Stephen Covey's 7 Habits of Highly Effective People.

\section{References}

Bullough, R. V. (2015). Differences? Similarities? Male teacher, female teacher: An instrumental case study of teaching in a Head Start classroom. Teaching and Teacher Education, 47, 13-21.

Covey, S. (2013). The seven habits of highly effective people: Powerful lessons in personal change $-25^{\text {th }}$ anniversary edition. New York, NY: Simon and Schuster.

Eisenhauer, M. J., \& Pratt, D. (2010). Capturing the image of a male pre school teacher. Young Children, 65(3), 12-16.

Johnson, S. P., Middleton, R., Nicholson, N., \& Sandrick, D. (2010). Still so few male teachers: Now what? Young children, 65(3), 18-23.

Nelson, B. G. (2010). From gender bias to gender equity in early childhood education staff. In L.Derman-Sparks, \& J. O. Edwards (Eds.), Anti-bias education for young children and ourselves (p. 100). Washington, DC: National Association for the Education of Young Children.

Pruit, J. C. (2014). Preconstructing suspicion and recasting masculinity in preschool settings. Qualitative Research in Education, 3(3), 320 -344 .

Said, E. (1978). Orientalism, New York, NY: Random House. 